\title{
Factors Related to Stunting in Toddlers
}

\author{
$1^{\text {st }}$ Indanah \\ D3 Nursing Program \\ Muhammadiyah University of Kudus \\ Kudus, Indonesia \\ indanah@umkudus.ac.id
}

\author{
$2^{\text {nd }}$ Ratna Dewi J \\ S1 Nursing Program \\ Muhammadiyah University of Kudus \\ Kudus, Indonesia \\ ratnadewi@gmail.com
}

\begin{abstract}
Stunting is a state of failure to thrive, occurring in children under 5 years of age. Stunting is a chronic malnutrition. The incidence of stunting according to the World Health Organization (WHO, 2012) is estimated that there are 162 million children under 5 year-old. The prevalence of stunting is a public health problem. The percentage of stunting in Indonesia is still categorized high and is a health problem that must be overcome. Many factors can cause stunting. The purpose of this study was to determine what factors are associated with the incidence of stunting in infants in the $X$ health center area of Kudus Regency. This study uses a case control design with a retrospective approach. Sampling using stratified random sampling technique with a sample of 90 toddlers. The results showed that there was a significant relationship between education, parental knowledge, history of immunization, history of breastfeeding, birth length, birth weight and eating patterns with the incidence of stunting ( $p$ value: 0.0000 )
\end{abstract}

Keywords—stunting, toddlers

\section{INTRODUCTION}

Stunted growth that reflects stunted growth due to malnutrition. Stunting is characterized by an index of body length compared to age $(\mathrm{L} / \mathrm{U})$ or height compared to age $(\mathrm{H}$ / U) with a Z-score limit of less than -2 SD [1]. According to WHO (2010) [1], Stunting reflects the nutritional status of less than chronic during growth and development since early life. Stunting is a form of growth failure (shaky growth) accumulated inadequate nutrition that lasts a long time.

The problem of short children (stunting) is one of the nutritional problems faced in the world, especially in poor and developing countries [2]. Stunting is a problem because it is associated with an increased risk of morbidity and death, suboptimal brain development so that motor development is delayed and stunted mental growth [2]. The prevalence of stunting in several countries in Southeast Asia, such as Myanmar by $35 \%$, Vietnam by $23 \%$, and Thailand by $16 \%$. The prevalence of stunting in Indonesia According to the 2013 Basic Health Research was $37.2 \%$, an increase from the year 2010 of $35.6 \%$ and in 2007 of $36.8 \%$. This means that the maximum growth is suffered by around 8 million children in Indonesia, or one in three children in Indonesia. The prevalence of stunting in Central Java is relatively high at $33.6 \%$ with details of $17 \%$ of short children and $16.9 \%$ of very short children [3]. The prevalence of stunting is even higher compared to nutritional problems in other toddlers such as malnutrition (19.6\%), thinness (6.8\%), and fat (11.9\%), (Millennium Challenge Account Indonesia 2015).

The tool to determine whether a child is stunted or not is a WHO table based on the WHO-NCHS Reference Standard and how to assess nutritional status using the Zscore rules listed in the Decree of the Minister of Health of the Republic of Indonesia Number:1995/MENKES/SK/XII/2010 About Antopometry Standards for Assessment of Child Nutritional Stantus. This stunting can be caused by direct or indirect factors. One of the direct causes of stunting is nutrition intake [4].

Stunting toddlers increase the risk of decreased intellectual ability, inhibits motor skills, productivity, and increases the risk of degenerative diseases in the future. This is because stunting children tend to be more prone to becoming obese, because people with short bodies should ideally also have a low body weight. just a few pounds can make a person's Body Mass Index (BMI) rise above normal limits.

Factors of parental education, behavior and genetics, socioeconomic conditions, breastfeeding, low birth length (LBL) and low birth weight (LBW) are factors related to stunting. One of the risk factors that influence the incidence of stunting in children under five is low birth weight (LBW) and low birth length (LBL). LBW and LBL will result in disruption of the growth of the baby, if this situation continues and the provision of food that can not meet the needs of the baby, often infected with infectious diseases can cause toddlers to become stunted [5].

Factors that cause stunting include incomplete basic immunization coverage and exclusive breastfeeding [1]. Immunization provides an immune effect against humans, needed especially at an early age which is an age vulnerable to disease [6]. In Indonesia, the coverage of complete basic immunization (CBI) in 2016 has not reached the target. The government is targeting cbi coverage of $91.5 \%$, but until the end of the year only $82.1 \%$ has been achieved. This figure is equivalent to 3,589,226 babies born throughout 2016 . Achievements in 2016 are different from 2015, which exceeded the target. CBI coverage reached $80 \%$, which is greater than the target of $75 \%$, the figure is equivalent to $4,139,903$ babies born a year ago. Giving immunization to children follows the existing schedule. By providing immunizations according to a predetermined schedule provides optimal immune formation results (antibodies) so as to protect children from exposure to disease.

WHO(world health organization) states that only $40 \%$ of babies in the world get exclusive breastfeeding while $60 \%$ of other babies have actually received non-exclusive breastfeeding when they are less than 6 months old. This illustrates that exclusive breastfeeding is still low while the practice of non-exclusive breastfeeding in various countries is still high. Data in Indonesia shows that exclusive 
breastfeeding coverage is only $42 \%$. This figure is clearly below the WHO target which requires coverage of breast milk up to $50 \%$. This figure indicates that only a few Indonesian children receive adequate nutrition from breast milk. Whereas breastfeeding plays an important role in the process of physical and mental development of children with long-term impacts [3]

Inadequate nutritional intake of children can lead to disruption of growth and development in children, even if the condition is not handled properly, the risk of illness and death of children will increase. Parents who will feed their children are related to parents' knowledge and parental education, this is due to the level of understanding and acceptance of information that parents will absorb about nutrition that will be given to their children. Parental education is closely related to the nutritional status of children because parents, especially mothers who directly care for children, including preparing and providing food to children. Septikasari, (2018) [7] states that the higher the level of one's education, the easier it is to be given an understanding of information, and the easier it is to implement knowledge in behavior, especially in terms of health and nutrition.

Regarding parents' feeding patterns to their children, the results of the study Nurbaiti et al, (2014) say that the customs and culture that have taken root greatly influence their behavior and living habits, including eating habits and daily eating patterns. The types of food ingredients and menus consumed, meal times, frequency of meals, food destination, to the types of food items taboo by the community are strongly influenced by their customs and culture. The same thing applies to children in the first 1,000 days of their lives. [8]

\section{METHOD}

This research is a quantitative study using analytic descriptions with a case control research design with a retrospective approach. The study was conducted for 2 months, namely March and April 2019. The population in this study were parents who had stunting and not stunting toddlers in the Kudus District Health Center area of 100 people. The sampling technique in this study uses Stratified random sampling technique for toddlers who are not stunted. The overall sample in this study was 90 parents of toddlers with details of 45 toddlers experiencing stunting and 45 toddlers not experiencing stunting. This study uses a questionnaire that has been tested for validity and reliability to assess the variables of knowledge, feeding patterns and history of breastfeeding. As for the LBL, LBW, Immunization History variables using the results recorded in the Children's KIA Handbook. For stunting criteria use Nutrition measurements from NCHS. The data in this study were analyzed using a computer program. Data were analyzed using univariate, and bivariate analysis. Using chi square analysis.

\section{RESULT AND DISCUSSION}

\section{A. Characteritics of Respondents}

Respondents in this study were mothers and toddlers in the District Health Center X Kudus District. Of the 90 respondents in the intervention group, the average toddler with an average age of 2.5 years and male sex $(57.8 \%)$. The average mother is
25 years old, most $(77.8 \%)$ as housewives, and have high school education $(47.8,3 \%)$

TABEL 1 TODDLER RESPONDENTS CHARACTERISTICS BASED ON AGE, BW, WL (N:90)

\begin{tabular}{|c|c|c|c|c|}
\hline Variable & Mean & SD & Min-Max & $95 \%$ CI \\
\hline $\begin{array}{c}\text { Age } \\
\text { (month) }\end{array}$ & 30,52 & 12,868 & $13-60$ & $27,83-33,22$ \\
\hline BW (gram) & 2910 & 567,152 & $2200-3900$ & $\begin{array}{c}2791,04- \\
3028,83\end{array}$ \\
\hline BL (cm) & 48,09 & 2,612 & $43-52$ & $47,54-48,64$ \\
\hline
\end{tabular}

Diagram 1 explains that based on PBL and BBL, out of 90 infants there are $42(47 \%)$ respondents who have Low BBL and $43(48 \%)$ have a body length that is less than normal. The results of the history of breastfeeding and breastfeeding history shows that $9(10 \%)$ respondents did not get complete immunizations and 48 (53\%) were not given breast milk exclusively. Eating patterns and Parental Knowledge are explained in Diagram 1 with the results that $45(50 \%)$ toddlers get good eating patterns and $52(58 \%)$ parents of toddlers have good knowledge about stunting

\section{B. Bivariate Analysis}

The results of the bivariate analysis of factors related to stunting can be explained in Table 2. In Table 2 it can be explained that all factors are related to the incidence of stunting in infants. This can be seen from the $\mathrm{p}$ value $=0.0000$ ( a <0.05). Based on the Odd Ratio for each variable, the variable pattern of parental feeding among toddlers shows a high number that is 462 which means that for toddlers who get poor diet, 462 times will be at risk of stunting.

There is a relationship between birth weight and the incidence of stunting. Birth weight is the most important anthropometric measure and is most often used in newborns (neonates). Birth weight (BW) is used to diagnose normal or Low Birth Weight (LBW) babies. For example babies born with low birth weight can be at risk of experiencing growth failure that can cause stunting. Mothers who have poor nutritional status, age of mothers who are too old and too young, maternal education, and diseases suffered by pregnant women such as anemia, asthma, hypertension, HIV / AIDS etc., are likely to give birth to babies with low birth weight (LBW) and premature is also greater. Low birth weight is a multi-picture picture of public health problems including mothers with long-term malnutrition, poor health, hard work and poor health care and pregnancy. Individually, LBW is an important predictor in the health and survival of newborns and is associated with high risk in children. The proportion of stunting toddlers is higher in toddlers with a history of low birth weight (Diagram 1). Babies born with Low Birth Weight ( $<2500$ grams) have the opportunity to experience stunting 16 times compared with babies born with normal weight.

Based on univariate analysis in Diagram 1, it can be concluded from 90 respondents that most respondents who had normal birth length were 47 respondents $(52.2 \%)$, while respondents who had low birth length (LBL) were 43 respondents $(47.8 \%)$. Based on the results of calculations with the chi square test obtained a significant level of $p=0,000$ $<0.005$. Thus it can be concluded that there is a relationship 
between the length of the body born with the incidence of stunting in Puskesmas X Kudus District.

Low birth length indicates that the child in the womb is experiencing a lack of nutritional intake so that the impact on the growth of children is not optimal but if after the child is born the child does not get adequate nutritional intake in a long time so that one of the impacts is the nutritional status of children is based on height and low age, which makes toddlers at risk of stunting.

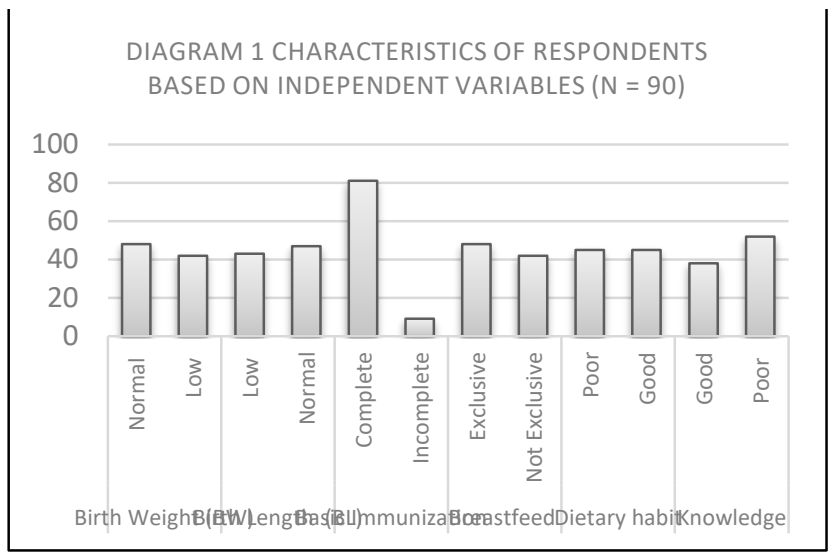

Low birth length indicates that the child in the womb is experiencing a lack of nutritional intake so that the impact on the growth of children is not optimal but if after the child is born the child does not get adequate nutritional intake in a long time so that one of the impacts is the nutritional status of children is based on height and low age, which makes toddlers at risk of stunting.

The poor and unequal status of the mother obtained by the mother during pregnancy, causing the child to be born with a nutritional state that is lacking. There is a relationship between the length of the body born with the incidence of stunting in infants in the working area of Health Center X Kudus Regency in 2019. The proportion of toddlers with stunting is more in infants with a history of less birth length. Toddlers with a long history of low birth weight are 16 times stunted.

History of immunization is to provide immunity against a particular disease. Children are immune or resistant to one disease but not necessarily immune to other diseases. Immunization is an effort to actively raise / increase a person's immunity to a disease, so that if one day exposed to the disease it will not hurt or only experience mild illness. For children who get complete basic immunization can prevent suffering or pain caused by diseases that are likely to cause disability or death. Benefits for the family and the country can improve the level of health and be able to create a strong and sensible nation to continue the country's development.

The relationship of immunization history with the incidence of stunting shows that children who do not have a complete history of immunization have a greater chance of experiencing stunting, which is 0.4 times compared to children who have a history of complete immunization

Exclusive breastfeeding is full breastfeeding for the first six months without giving food or other drinks to the baby. For newborn babies scientifically get immunoglobulin (immune or immune substances) through the placenta, but the levels of these substances will quickly decrease immediately after birth.
This gap can only be eliminated or reduced by breastfeeding. Mother's milk contains immunity or immune system so that it can be a protection for babies from various infectious diseases such as bacteria, viruses, and fungi. Children who are not breastfed for 6 months are counted after birth, the child is susceptible to infection. The relationship of history of breastfeeding with the incidence of stunting shows that children who are not exclusively breastfed have 37 times the chance to experience stunting. The proportion of stunting toddlers is higher in toddlers who are not exclusively breastfed (Table 1).

TABLE 2

CHARACTERISTICS OF RESPONDENTS BASED ON FACTORS RELATED TO STUNTING $(\mathrm{N}=90$

\begin{tabular}{|c|c|c|c|}
\hline No & Variable & OR & P value \\
\hline 1 & Birth Weight ( BW) & $\begin{array}{c}16 \\
(5,349-147,858)\end{array}$ & 0,000 \\
& & 16,188 & 0,000 \\
\hline 2 & Birth Length (BL) & $(5,732-45,717)$ & \\
\hline 3 & Basic Immunization & 0,444 & 0,000 \\
& & $(0,348-0,567)$ & 0,000 \\
\hline 4 & Breastfeed & 37 & 0,000 \\
\hline 5 & Dietary habit & 462,250 & \\
& & $3432,803)$ & 0,000 \\
\hline 6 & Knowledge & $(17,452-423,780)$ & \\
& & & \\
\hline
\end{tabular}

The relationship of immunization history with the incidence of stunting shows that children who do not have a complete history of immunization have a greater chance of experiencing stunting, which is 0.4 times compared to children who have a history of complete immunization

There was a significant relationship between feeding patterns and the incidence of stunting among children at Puskesmas X Kudus District in 2019 (p value 0,000; a $<0.005$ ). As children age, the food they provide must be more diverse and nutritious and balanced in order to support the nutritional status and growth and development of children. The mother plays an important role in determining the types of food that will be consumed by children. Provision of adequate eating patterns associated with good quality food consumption of children which will ultimately increase the adequacy of nutrients as well. The level of nutrient adequacy is one of the factors that can affect the nutritional status of children under five. Toddlers who are not good in feeding patterns will have the opportunity to experience stunting 462 times (table 1). The proportion of stunting toddlers is more in toddlers who are less good in their feeding patterns. Inadequate nutritional intake of children can lead to disruption of growth and development in children, even if the condition is not handled properly, the risk of illness and death of children will increase.

Parents who will feed their children are related to parental knowledge and parental education, this is due to the level of understanding and acceptance of information that parents will absorb about nutrition to be given to their children. The level 
of maternal knowledge about nutrition is one of the factors that can influence the occurrence of stunting in children under five, both in rural and urban areas. Knowledge about nutrition is the initial process in changing behavior to improve nutritional status, so knowledge is an internal factor that influences behavior change. The mother's knowledge about nutrition will determine the mother's behavior in providing food for her child. Mothers with good nutritional knowledge can provide food with the right type and amount to support the growth and development of children under five. There is a relationship between parents' knowledge about nutrition with the incidence of stunting. Parental knowledge about poor nutrition will provide an opportunity 86 times for toddlers to experience stunting. The proportion of toddlers with stunting is more for mothers of toddlers who have less knowledge about toddler nutrition.

\section{CONCLUSION}

The main conclusion of this study is that there is a significant relationship between independent variables (PBL, BBL, Immunization History, History of Breastfeeding, Feeding Patterns and Parental Knowledge) with stunting events in Puskesmas X Kudus District in 2019 with a p value $<0,000$ ( a :0.05). Toddlers who are not good in feeding patterns have 462 chances of experiencing stunting.

\section{ACKNOWLEDGMENT}

I wish to express my deep thanks to all the members of the Department of Nursing, Muhammadiyah University of Kudus for their kindness and helps to my articles.

\section{REFERENCES}

[1] W. H. Organization, "Nutrition Landscape Information system (NLIS) Country Profile Indicators: Interpretation guide," World Health Organization, Geneva, 2010.

[2] UNICEF, "Ringkasan Kajian Gizi Bulan Oktober 2012," UNICEF Indonesia, Jakarta , 2012.

[3] RIskesdas, "Riset Kesehatan DAsar," RIskesdas, 2013, 2013.

[4] Bappenas, "Kerangka Kebijakan Gerakan Sadar Gizi dalam Rangka Seribu Hari Pertama Kehidupan (1000 HPK). Jakarta: Badan Perenc Pembangunan Nasional," Bappenas, Jakarta, 2013.

[5] D. Nasution, D. S. Nurdiati and E. Huriyati, "Low Birth Weight (LBW) with Stunting in Children 6-24 Months," Low Birth Indonesian Clinical Nutrition Journal, pp. 31-32, 2014..

[6] S. Riyadi and Sukarmin, Asuhan Keperawatan Pada Anak, Jogjakarta: Graha Ilmu, 2012.

[7] M. Septikasari, Status Gizi Anak dan Faktor yang Mempengaruhi, Jogyakarta: UNY Press, 2018.

[8] L. Nurbaiti, A. C. Adi, S. R. Devi and E. Huriyati, "Berat Badan Lahir Rendah (BBLR) dengan Kejadian Stunting pada Anak Usia 6-24 Bulan," Jurnal Gizi Klinik Indonesia, pp. 31-32, 2014.

[9] D. K. K. Kudus, "Laporan Hasil Pemantauan Status Gizi Balita Berdasarkan Pengukuran TB/U di Kabupaten Kudus," Dinas Kesehatan Kabupaten Kudus, Kudus, 2017.

[10] D. K. K. Kudus, "Data Dinas Kesehatan Kabupaten Kudus," Dinas Kesehatan Kabupaten Kudus, Kudus, 2018. 